\title{
Comorbidities of patients in tiotropium clinical trials: comparison with observational studies of patients with chronic obstructive pulmonary disease
}

This article was published in the following Dove Press journal:

International Journal of COPD

16 March 2015

Number of times this article has been viewed

\author{
Marc Miravitlles' \\ David Price ${ }^{2}$ \\ Klaus F Rabe ${ }^{3,7}$ \\ Hendrik Schmidt ${ }^{4}$ \\ Norbert Metzdorf ${ }^{5}$ \\ Bartolome Celli ${ }^{6}$
}

'Pneumology Department, Hospital Universitari Vall d'Hebron, Ciber de Enfermedades Respiratorias (CIBERES), Barcelona, Spain;

${ }^{2}$ Academic Primary Care, Division of Applied Health Sciences, University of Aberdeen, Aberdeen, UK;

${ }^{3}$ Department of Medicine, ChristianAlbrechts-Universität zu Kiel (CAU), Großhansdorf, Germany; ${ }^{4}$ Global

Biometrics and Clinical Applications, Boehringer Ingelheim Pharma GmbH and Co KG, Ingelheim am Rhein, Germany; ${ }^{5} \mathrm{TA}$ Respiratory Diseases, Boehringer Ingelheim Pharma GmbH and Co KG, Ingelheim am Rhein,

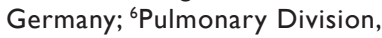
Brigham and Women's Hospital, Boston, MA, USA; ${ }^{7}$ LungenClinic Grosshansdorf, Großhansdorf, Germany
Correspondence: Marc Miravitlles Servei de Pneumologia, Hospital Universitari Vall d'Hebron, P Vall d'Hebron I19-129, 08035 Barcelona, Spain

Tel +3493274 6I57

Fax +34932746083

Email mmiravitlles@vhebron.net
Background: There is an ongoing debate on whether patients with chronic obstructive pulmonary disease (COPD) seen in real-life clinical settings are represented in randomized controlled trials (RCTs) of COPD. It is thought that the stringent inclusion and exclusion criteria of RCTs may prevent the participation of patients with specific characteristics or risk factors.

Methods: We surveyed a database of patients recruited into 35 placebo-controlled tiotropium RCTs and also conducted a systematic literature review of large-scale observational studies conducted in patients with a documented diagnosis of COPD between 1990 and 2013. Patient demographics and comorbidities with a high prevalence in patients with COPD were compared between the two patient populations at baseline. Using the Medical Dictionary for Regulatory Activities (MedDRA; v 14.0), patient comorbidities in the pooled tiotropium RCTs were classified according to system organ class, pharmacovigilance (PV) endpoints, and Standardised MedDRA Queries to enable comparison with the observational studies.

Results: We identified 24,555 patients in the pooled tiotropium RCTs and 61,361 patients among the 13 observational studies that met our search criteria. The Global initiative for chronic Obstructive Lung Disease (GOLD) staging of patients in the RCTs differed from that in observational studies: the proportion of patients with GOLD stages I+II disease ranged from $40.0 \%$ to $51.5 \%$ in the RCTs but $24.5 \%$ to $44.1 \%$ in the observational studies; for GOLD stage III or IV disease these ranges were $7.2 \%-45.8 \%$ (RCTs) and $13.7-42.1 \%$ (observational studies). The comorbidities with the highest prevalence reported in the RCTs and observational studies were: hypertension $(39.4 \%-40.0 \%$ vs $40.1 \%-60.6 \%)$, other ischemic heart disease $(12.3 \%-14.2 \%$ vs $12.5 \%-41.0 \%)$, diabetes $(10.3 \%-10.9 \%$ vs $4.0 \%-38.9 \%)$, depression $(8.5 \%-9.5 \%$ vs $17.0 \%-20.6 \%)$, and cardiac arrhythmia (7.8\%-11.4\% vs $11.3 \%-15.8 \%)$.

Conclusion: The clinical profile of COPD patients treated in the tiotropium trial program appears to be largely in the range of clinical characteristics, including cardiovascular comorbidities, reported for "real-life patients." The tiotropium RCTs tended to include patients with more severe disease than the observational studies.

Keywords: patient population, baseline characteristics, epidemiology, real-life patients, GOLD staging

\section{Introduction}

Randomized controlled trials (RCTs) provide the best evidence to support the efficacy and safety of therapies and form the basis for regulatory approval of treatment for all diseases, including chronic obstructive pulmonary disease (COPD). A well-designed RCT has a high degree of internal validity and allows for data-driven determination of whether a cause-effect relationship exists between a study drug and its outcome. Patient populations in RCTs are subject to stringent inclusion and exclusion criteria, 
and thus could be perceived as having an inherent lack of external validity. ${ }^{1-4}$ Furthermore, because patients entering RCTs are selected, their characteristics and concomitant treatment regimens may not reflect daily clinical practice. ${ }^{5}$ Randomization and stringency in inclusion and exclusion criteria are nevertheless important for determining the comparative efficacy and safety of the study drug, limiting the potential for confounding and excluding patients at specific risks.

To bridge the gap between RCTs and how medications are used by clinicians in daily practice, noninterventional, or observational, studies or analyses of existing databases are conducted. Unlike RCTs, observational studies normally have less stringent inclusion and exclusion criteria and thus may provide a broader perspective on disease background, comorbid conditions, treatment patterns, and outcomes. Observational studies are also more representative of normal patterns of care. ${ }^{4}$ Because they are more representative of daily clinical practice, observational studies have high external validity and can be generalized, ${ }^{4}$ but can also be more prone to assessment bias ${ }^{1}$ and outcomes may be confounded, in contrast to RCTs. ${ }^{6}$

According to published epidemiological and observational studies, some comorbid conditions with a high prevalence in patients with COPD include hypertension, ischemic heart disease, hypercholesterolemia, diabetes, arrhythmias, interstitial lung disease, lung cancer, anxiety, and depression. $^{7-12}$

Based on the ongoing scientific discussion around the external validation of RCTs, ${ }^{13-15}$ we sought to understand how representative the patients included in RCTs are to patients in a real-life clinical setting, and how the inclusion and exclusion criteria implemented for these trials may have influenced the recruited patient population. In particular, it is important to know whether patients with comorbidities are adequately represented in clinical trials of COPD, or whether they are deselected by exclusion criteria - or simply not recruited in sufficient numbers. To achieve this goal, we surveyed a database of patients recruited into tiotropium RCTs and also conducted a systematic literature review of large-scale observational studies in order to compare the demography and baseline characteristics of the RCT population with "real-life" patient populations.

\section{Methods}

\section{Analysis of tiotropium RCTs}

Data on patient baseline characteristics were taken from a database (Boehringer Ingelheim $\mathrm{GmbH}$, Ingelheim am Rhein, Germany) of 28 placebo-controlled clinical trials conducted with a tiotropium HandiHaler ${ }^{\circledR}\left(\right.$ SPIRIVA $^{\circledR}$, Boehringer
Ingelheim $\mathrm{GmbH}$ ) and seven placebo-controlled trials using the tiotropium Respimat ${ }^{\circledR}$ Soft Mist ${ }^{\mathrm{TM}}$ Inhaler (SPIRIVA ${ }^{\circledR}$, Boehringer Ingelheim $\mathrm{GmbH}$ ). The 4-year Understanding the Potential Long-term Impacts on Function with Tiotropium $\left(\right.$ UPLIFT $^{\circledR}$ ) trial (trial number 205.235) contributed the largest portion of patients to the placebo-controlled HandiHaler ${ }^{\circledR}$ database population (Table S1).

Statistical analysis was based on descriptive characterization of the pooled trials.

\section{Design of the RCTs in the analysis}

Studies were randomized, placebo-controlled, double-blind, parallel-group trials of $\geq 4$ weeks' duration, assessing either tiotropium HandiHaler ${ }^{\circledR} 18 \mu \mathrm{g}$ (once daily) or tiotropium Respimat $^{\circledR} 5 \mu \mathrm{g}$ (two puffs of $2.5 \mu \mathrm{g}$ once daily) for the indication of COPD. Written informed consent was obtained from all patients and ethics committee approval was obtained for all protocols. As all trials were part of the tiotropium COPD development program, inclusion and exclusion criteria were similar across all trials. However, later trials were modified to have somewhat broader selection criteria (see inclusion and exclusion criteria). Principal patient characteristics like age, sex, anthropometrics, and ethnicity were recorded for all patients at baseline. Lung function (as measured by forced expiratory volume in 1 second $\left[\mathrm{FEV}_{1}\right]$ ) and smoking history were also captured for the entire population.

\section{Inclusion criteria of the RCTs in the analysis}

The key inclusion criteria common to all tiotropium trials were: diagnosis of COPD, $\mathrm{FEV}_{1}$ /forced vital capacity ratio $\leq 70 \%$, age $\geq 40$ years, and $\geq 10$ pack-years' smoking history. Other inclusion criteria such as $\mathrm{FEV}_{1}$ cutoffs and requirement for exacerbation history varied between studies.

\section{Exclusion criteria of the RCTs in the analysis}

The key exclusion criteria were: diagnosis of asthma, symptomatic prostatic hypertrophy or bladder neck obstruction, narrow-angle glaucoma, and known hypersensitivity to the study medication or components. For practical reasons, significant disease other than COPD that could significantly confound the study results or preclude study completion was also an exclusion criterion. Other exclusion criteria in earlier trial protocols were: heart failure resulting in hospitalization in the previous 3 years, cardiac arrhythmia requiring drug treatment, or myocardial infarction (MI) within the past year. Nevertheless, heart failure and ischemic heart disease were not necessarily exclusion criteria. Cardiac exclusion criteria were more liberal in more recent trials such as UPLIFT $^{\circledR}$ 
with HandiHaler ${ }^{\mathbb{B}}$ and trial number 205.372 with Respimat ${ }^{\mathbb{R}}$ (Table S1). Drug therapy for arrhythmias was permitted, provided the therapy was stable and the patient had no history of a life-threatening arrhythmia or pacemaker insertion. In addition, the criterion for recent MI was decreased to 6 months.

Use of theophylline, inhaled corticosteroids, $\leq 10 \mu \mathrm{g}$ daily doses of oral corticosteroids (provided the dosing was stable), and short-acting $\beta_{2}$-agonists was permitted in all trials. The 4-year UPLIFT ${ }^{\circledR}$ trial $(5,992$ patients $),{ }^{16}$ as well as trial numbers $205.259,{ }^{17} 205.266$ (1,829 patients), ${ }^{18} 205.270,{ }^{19}$ $205.282,{ }^{20} 205.284,{ }^{21} 205.368,{ }^{22}$ and $205.372^{23}$ also permitted use of long-acting $\beta_{2}$-agonists (LABAs) as prescribed. Nonstudy inhaled anticholinergics had to be withdrawn during the conduct of all studies.

\section{Definitions of comorbidities}

The Medical Dictionary for Regulatory Activities (MedDRA) version 14.0 was used to code relevant medical history/ concomitant diagnoses (within the past 5 years) as reported by the investigator at baseline; preferred terms (PTs) were categorized under system organ classes (SOCs) within MedDRA. For conditions that are known to have a high prevalence in patients with COPD, MedDRA PTs denoting similar conditions were pooled as pharmcovigilance (PV) endpoints and Standardised MedDRA Queries (SMQs).

\section{Systematic literature review of observational studies}

To identify suitable studies, a systematic literature search of studies reporting comorbidities among patients with COPD was conducted in the following databases: (1) MEDLINE ${ }^{\circledR}$ 1990, May 14, 2013; (2) BIOSIS Previews ${ }^{\circledR}$ 1993-2008, May 2013; (3) EMBASE Alert, May 14, 2013; (4) EMBASE 1993, May 15, 2013; and (5) SciSearch ${ }^{\circledR}$ 1990, May 2013.

The inclusion and exclusion criteria for the literature review are detailed in Figure 1. The inclusion criteria for the literature search did not specify how patient demography and comorbidity data were presented. It was only important that this information be reported. For this reason, the number of studies used for the individual analyses will vary.

\section{Results}

In total, 17,990 and 6,565 patients were included in the HandiHaler $^{\circledR}$ and Respimat ${ }^{\circledR}$ trials, respectively. For the systematic literature search, using the search parameters detailed in the "Methods" section, 806 study publications were returned. Following a secondary screen to exclude all studies reporting RCTs, hospitalized patient populations, age-restricted populations, or reported study populations of fewer than
900 patients, 793 studies were excluded and 13 epidemiological and observational studies ${ }^{12,24-38}(n=61,361$ patients) were included for comparison with the anthropometrics of patients with COPD recruited in tiotropium RCTs (Table S2).

\section{Baseline demographics and clinical characteristics}

The baseline demographics (Table 1) of the placebo and tiotropium groups were balanced between patient populations in the pooled HandiHaler ${ }^{\circledR}$ and Respimat ${ }^{\circledR}$ trials, with $34.1 \%-37.6 \%$ of patients enrolled in the tiotropium RCTs identified as current smokers, compared with 36.2\%-43.0\% in the observational studies. Patients enrolled in the tiotropium RCTs had a mean baseline post-bronchodilator $\mathrm{FEV}_{1}$ of 1.18 $\pm 0.47 \mathrm{~L}$ standard deviation (SD) and $1.11 \pm 0.41 \mathrm{~L} \mathrm{SD}$, for HandiHaler ${ }^{\circledR}$ and Respimat ${ }^{\circledR}$ trials, respectively, that were $41.5 \%$ and $40.2 \%$ of postbronchodilator $\mathrm{FEV}_{1}$ predicted, for HandiHaler ${ }^{\circledR}$ and Respimat ${ }^{\circledR}$ trials, respectively. In the observational studies, the mean baseline post-bronchodilator $\mathrm{FEV}_{1}$ ranged from $47.0 \%-56.7 \%$ of predicted. The distribution of patients with COPD enrolled in the tiotropium RCTs by Global Initiative for Chronic Obstructive Lung Disease (GOLD) stage was 51.5\% and 40.0\% (GOLD stages I-II), $39.8 \%$ and $45.8 \%$ (GOLD stage III), and $7.2 \%$ and $13.6 \%$ (GOLD stage IV) for HandiHaler ${ }^{\circledR}$ and Respimat ${ }^{\circledR}$ trials, respectively. In the comparison observational studies, there were more patients enrolled with mild to moderate disease (GOLD stage I+II; 24.5\%-44.1\%), compared with GOLD disease stages III or IV (13.7\%-42.1\%; Table 2).

Although all of the observational studies reported baseline comorbidities in the patient population, they differed in how this was reported. In some instances, these were reported either by SOC or PT. The observational studies also differed in the level of additional information reported, relating to patient baseline characteristics and baseline concomitant medications. For this reason, the numbers of studies included in the comparisons of these parameters differ in Tables 2-4.

\section{Baseline comorbidities}

The majority of patients in the HandiHaler ${ }^{\circledR}$ and Respimat $^{\circledR}$ trials were diagnosed with comorbidities at baseline (79.4\% and $74.2 \%$, respectively), with vascular and cardiac disorders being the most frequent $(39.3 \%$ and $24.6 \%$ in the HandiHaler $^{\circledR}$ trials, respectively, and $40.1 \%$ and $24.3 \%$ in the Respimat ${ }^{\circledR}$ trials, respectively) (Table 3). The incidence of comorbidities was similar between the placebo and tiotropium treatment groups in both sets of trials. In four observational studies that enrolled a total of 17,048 patients with COPD, associated comorbidities grouped by SOC 
included cardiac $(9.4 \%-32.3 \%)$, vascular $(11.4 \%-45.0 \%)$, metabolic and nutritional $(9.9 \%-22.2 \%)$, and psychiatric (11.9\%) disorders (Table 3 ).

For comorbidities that are known to have a high prevalence in patients with COPD (hypertension, ischemic heart disease, dyslipidemia, diabetes, anxiety, and depression), SMQs or PV endpoints were used for the RCTs and applicable PTs were grouped to combine endpoints for observational studies in order to evaluate their prevalence in study populations at baseline (Table 4 and Table S3).

Observational studies of COPD that report comorbidities: 2000-2013

\section{Databases:}

1) MEDLINE ${ }^{\circledR}$ 1990, May 14, 2013; 2) BIOSIS Previews ${ }^{\circledR} 1993-2008$, May 2013;

3) EMBASE Alert, May 14, 2013; 4) EMBASE 1993, May 15, 2013; and

5) SciSearch ${ }^{\circledR} 1990$, May 2013.

\section{Inclusion criteria:}

- All records containing COPD, or Chronic Obstructive within three words of Disease, in the title, identifier or descriptor fields

- Published between 2000 and 2013

- Comorbidit(-ies, -y) or Co-Morbidit(-ies, -y) appeared in the title, identifier or descriptor fields

- Concomitant within two words of Disease(-s) or Disorder(-s) appeared in the abstract field

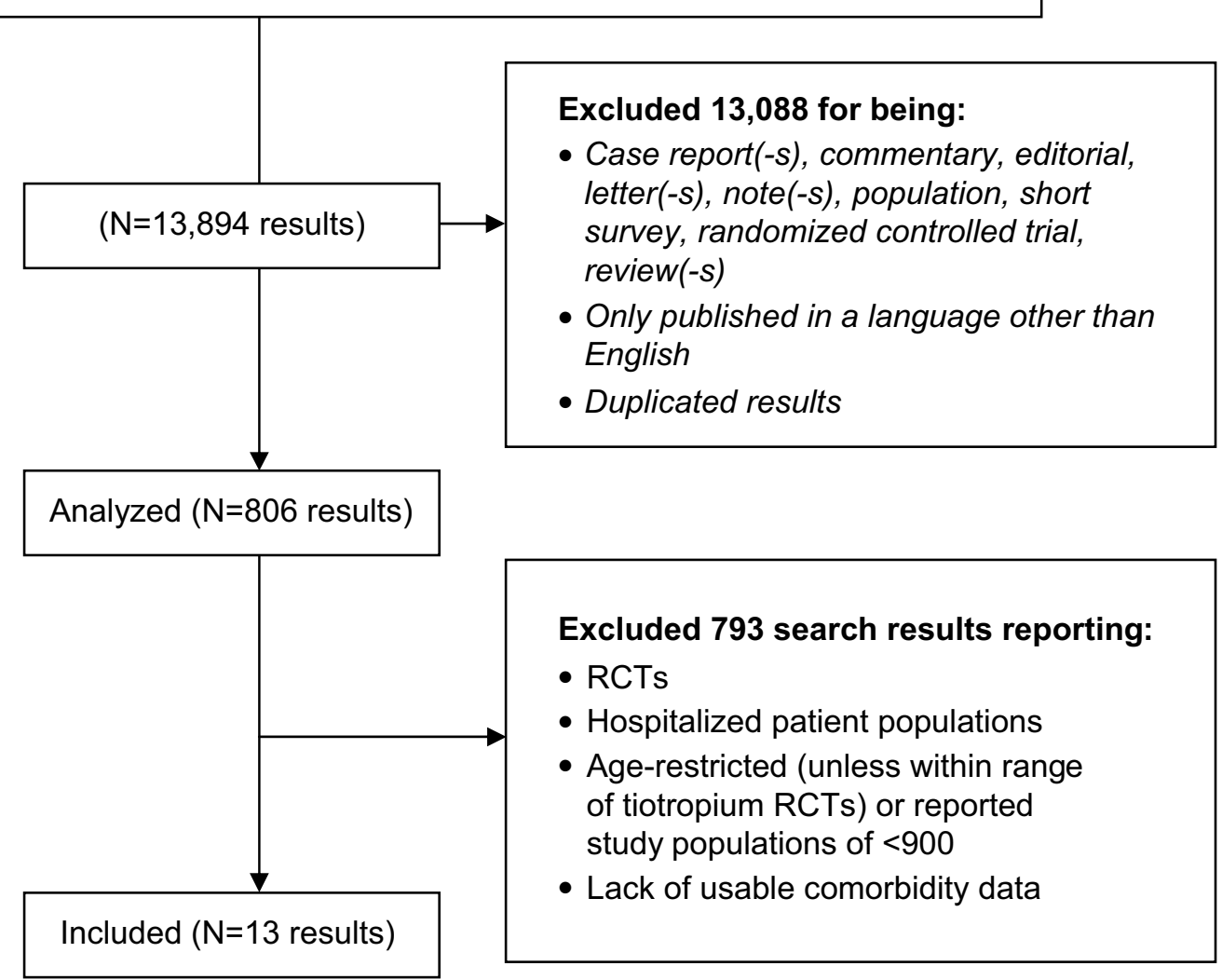

Figure I Systematic literature review of observational studies.

Abbreviations: COPD, chronic obstructive pulmonary disease; RCTs, randomized controlled trials. 


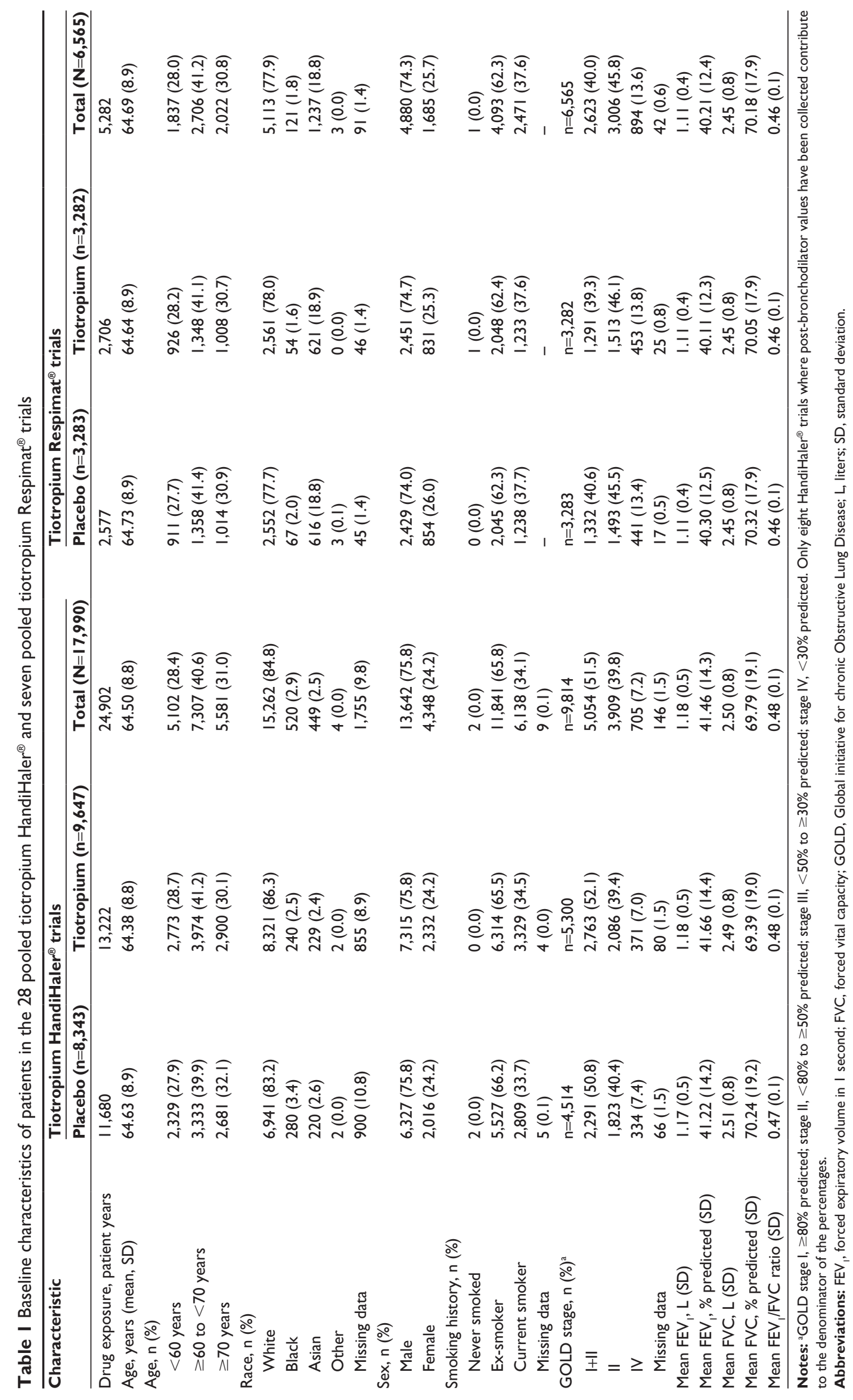



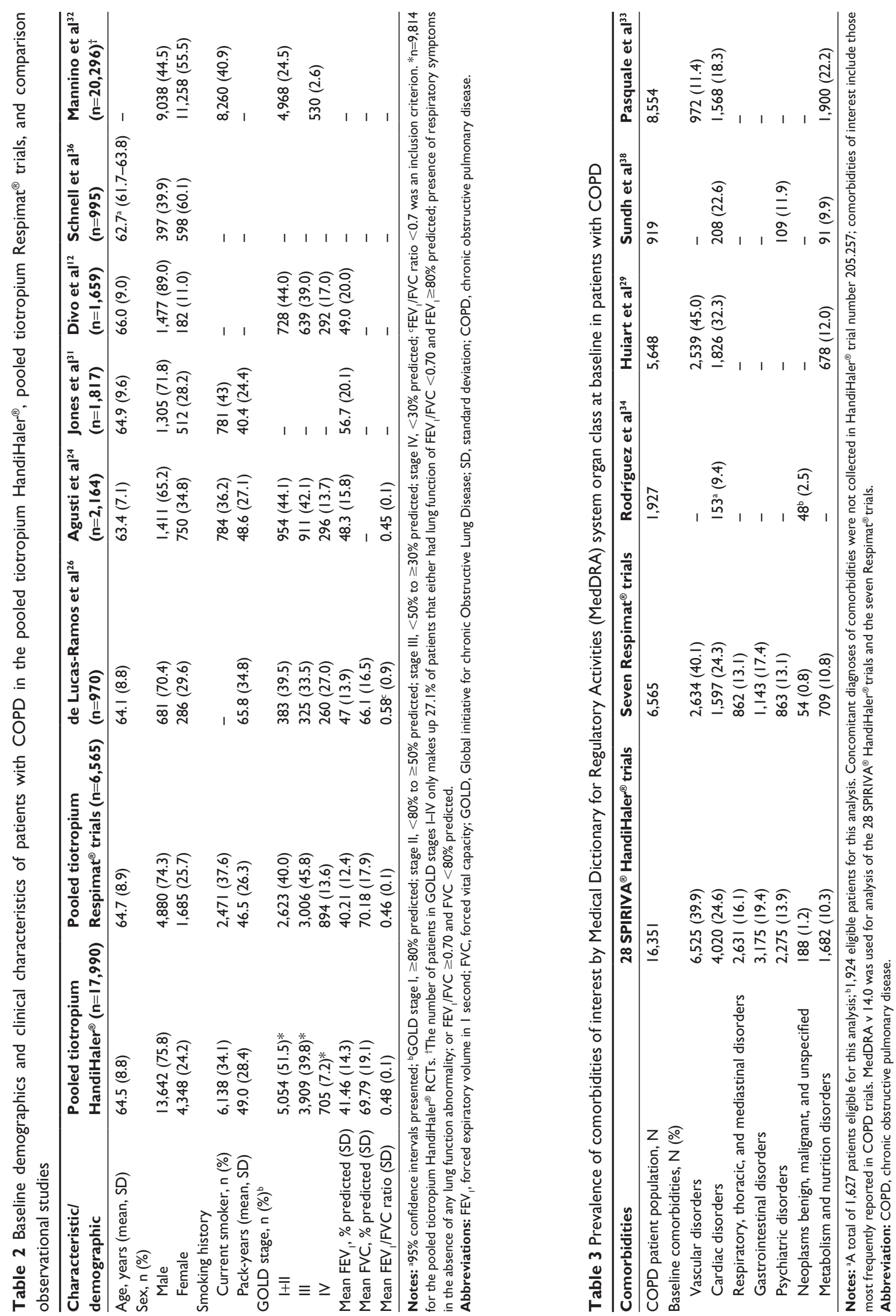


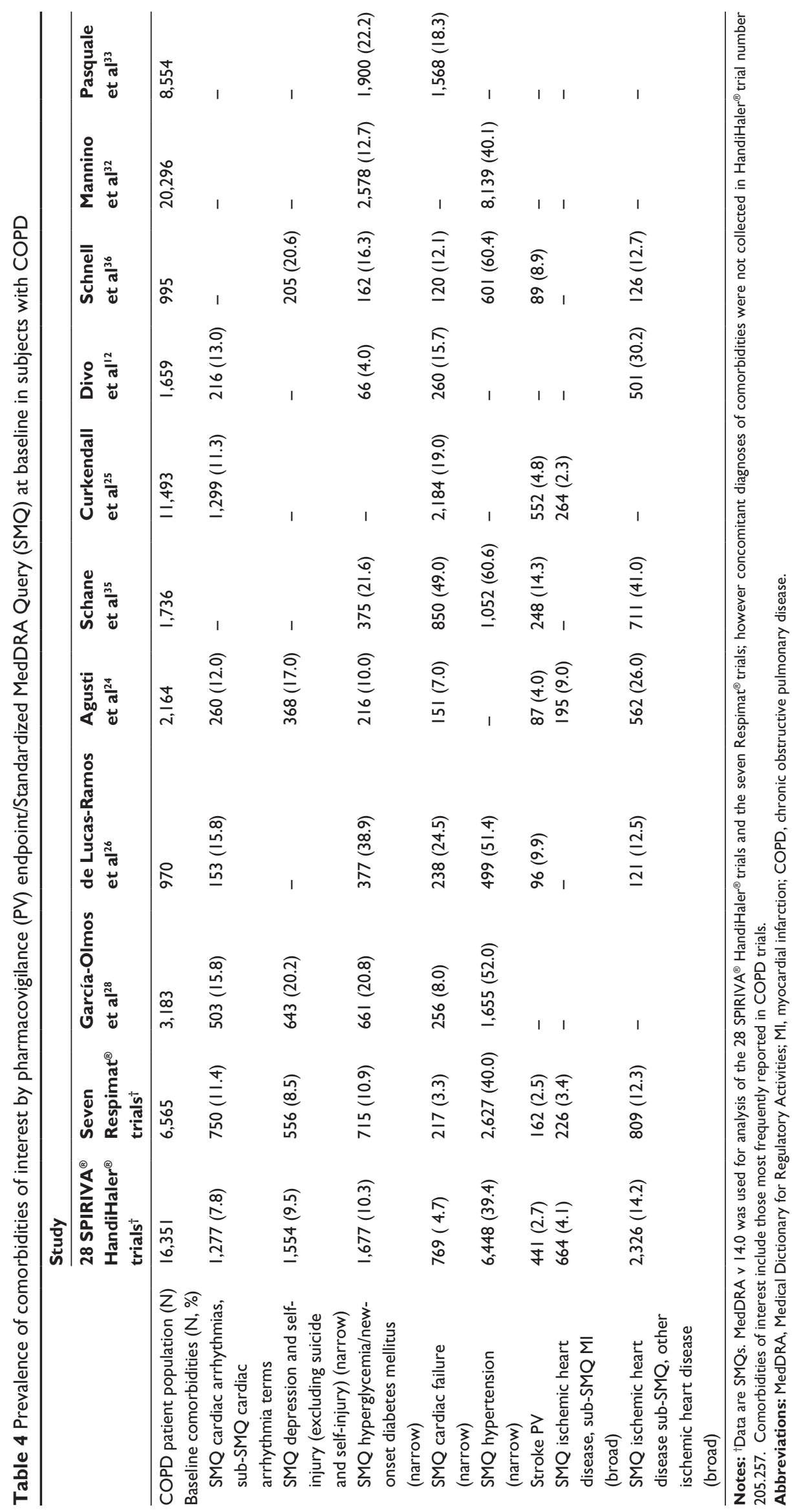


Hypertension was diagnosed in $39.4 \%$ of patients in the HandiHaler $^{\circledR}$ and $40.0 \%$ of patients in the Respimat ${ }^{\circledR}$ trials. Diagnoses of ischemic heart disease (14.2\% and $12.3 \%)$ cardiac arrhythmias (7.8\% vs $11.4 \%)$, depression $(9.5 \%$ vs $8.5 \%$ ), and diabetes (10.3\% vs $10.9 \%$ ) were similar in the pooled HandiHaler ${ }^{\circledR}$ and Respimat ${ }^{\circledR}$ trials, respectively (Table 4).

When reported by applicable PTs, the comorbidities with the highest prevalence in epidemiological and observational studies were hypertension (40.1\%-60.6\%), cardiac arrhythmia (11.3\%-15.8\%), depressed mood (17.0\%-20.6\%), cardiac failure $(7.0 \%-49.0 \%)$, and ischemic heart disease $(12.5 \%-41.0 \%$, Table 4$)$. In UPLIFT ${ }^{\circledR}$, increases in comorbid conditions from baseline to year 4 were observed (Table S4).

\section{Discussion}

We have analyzed the demographic data of patients in randomized, placebo-controlled clinical studies with tiotropium HandiHaler $^{\circledR}$ and Respimat ${ }^{\circledR}$ of at least 4 weeks' duration and compared these with data from epidemiological and observational studies. The background for this comparison was that, recently, several authors questioned the validity of RCTs for the evaluation of the safety of drugs in the treatment of COPD in clinical practice. ${ }^{13,14}$ The pivotal argument for these concerns was that the inclusion and exclusion criteria of RCTs prevent patients at greater risk (notably of cardiovascular [CV] risk) from participating in these studies. This could then potentially lead to a more positive safety evaluation of the drugs in question compared with clinical practice in a real-life setting.

This study of the characteristics of the 24,555 patients included in the randomized trials of tiotropium showed that the clinical profile, including age, sex, smoking history, and anthropometrics of these patients, is similar to that observed in large epidemiological and observational studies of patients with COPD. However, the proportions of patients with mild to moderate disease (GOLD stages I+II) ranged from $24.5 \%$ to $44.1 \%$ in the observational studies but from $40.0 \%$ to $51.5 \%$ in the tiotropium trials, while patients with severe disease (GOLD stage III or IV) were represented in similar numbers in the tiotropium RCTs $(7.2 \%-45.8 \%)$ as in the observational studies $(13.7 \%-42.1 \%)$.

\section{Comorbidities}

The most prevalent comorbidities reported by SOC observed in the COPD patient population at baseline in the pooled tiotropium trials were: cardiac, vascular, respiratory, gastrointestinal, psychiatric, and metabolic disorders. These were represented in the observational studies in similar proportions (Table 3 ). In particular, the prevalence of cardiac disorders in the 22,916 evaluable patients in the tiotropium RCT population was $24.3 \%-24.6 \%$. Of the 17,048 patients with COPD in the epidemiologic/observational studies, ${ }^{21,25,26,30}$ the prevalence of cardiac disorders was in the range of $9.4 \%-32.3 \%$. In a recent letter to the editor, ${ }^{39}$ the authors conducted an audit of patients discharged from hospital in New Zealand after an exacerbation of COPD and found that $38 \%$ patients prescribed tiotropium had comorbidities that would have made them ineligible for participation in UPLIFT $^{\circledR}$. Based on this observation, the authors concluded that the findings from UPLIFT ${ }^{\circledR}$ had limited generalizability to clinical practice in New Zealand. However, this New Zealand patient population is a very severe population of patients that required hospital admission, whereas patients included in UPLIFT $^{\circledR}$, as in all major clinical trials of COPD, consisted of ambulatory patients. The pattern of comorbidities of very severe admitted patients may differ, but this New Zealand patient population represents a minority of patients with COPD of special severity with increased risks of side effects secondary to all drugs and that require a personalized approach with careful evaluation of the expected benefits and risks of any given treatment.

Although it was excluded from our systematic literature review because it is a pooled analysis of epidemiological studies, validation of the current analysis is provided by a study conducted by Patel and Hurst. ${ }^{40}$ Using data from two large, population-based epidemiological studies (the Atherosclerosis Risk in Communities [ARIC] Study and the Cardiovascular Health Study [CHS], 20,296 adults aged $>44$ years $),{ }^{40}$ they reported that the prevalence of $\mathrm{CV}$ disease (defined as a composite of ischemic heart disease, heart failure, stroke, and/or transient ischemic attack) in patients with COPD was $20.0 \%-22.0 \%$. This is similar to the $24.6 \%$ and $24.3 \%$ prevalence of cardiac disorders that we determined in the tiotropium trials. This contradicts the concerns that the inclusion and exclusion criteria of tiotropium RCTs prevent patients at greater risk (notably of CV risk) from participating in these studies.

Comorbidities of interest were selected on the basis of being the most frequently reported in COPD trials and also to maximize the degree of comparisons with the observational studies identified in our systematic literature review. For eight selected comorbidities of interest (Table 4), our analysis revealed that hypertension had the highest prevalence in patients enrolled in tiotropium RCTs $(39.4 \%-40.0 \%)$. 
This was lower than the range $(51.4 \%-60.6 \%)$ reported in four out of nine observational studies ${ }^{26,28,32,35,36}$ (total: 6,884 patients) used in our comparison. However, in a populationbased National Institutes of Health cohort of 20,296 patients with COPD aged $\geq 45$ years, the prevalence of hypertension was $40.1 \%,{ }^{32}$ similar to that reported for patients in tiotropium RCTs.

Although not included in our current analysis because it is not among the most frequently reported comorbidities among patients with COPD, two reports, by Verhamme et $\mathrm{al}^{41}$ and Mathioudakis et $\mathrm{al}^{42}$ have suggested an association between mortality and renal impairment in patients with COPD treated with tiotropium via HandiHaler ${ }^{\circledR}$ or Respimat $^{\circledR}$. A pooled safety analysis of tiotropium delivered via the HandiHaler ${ }^{\circledR}$ or the Respimat ${ }^{\circledR}$ Soft Mist ${ }^{\text {TM }}$ Inhaler that encompasses 22 Phase III and IV tiotropium clinical trials and evaluated 10,805 patients showed that that there was no trend for increased incidence rate ratios of adverse events with worsening renal function for either tiotropium HandiHaler $^{\circledR}$ or Respimat ${ }^{\circledR}$. (Table S5). ${ }^{43}$

\section{Limitations of the study}

A major limitation of this study is the difference in the reporting of baseline characteristics and comorbidities in the observational studies identified in our systematic literature review. Only six of the observational studies reported the GOLD staging of patients. Although included in this comparison, Mannino et al's study ${ }^{32}$ reports GOLD staging for only $27.1 \%$ of the patients enrolled, which complicates interpretation of these results. Furthermore, four studies reported baseline comorbidities by SOC, and none of these allowed for a full comparison with the tiotropium RCTs. This means that for comorbidities such as respiratory, thoracic and mediastinal disorders, gastrointestinal disorders, psychiatric disorders, and neoplasms, the patient population against which the tiotropium RCT population is compared is limited (only 2,846 from two of the four observational studies as compared with 22,916 in the tiotropium RCTs combined). This variability complicates interpretation of these results due to the limited sample size. Although this situation is repeated for comparison of baseline comorbidities in Table 4, it is mitigated to some extent by the inclusion of 51,050 patients from nine out of 13 observational studies for comparison to the 22,916 patients identified in the included tiotropium RCTs.

Another limitation of this study is that it does not take into account the various factors that add to the complexity of studying comorbidities in patients with COPD. These include: smoking status, which has been shown to be a risk factor for diabetes mellitus and dyslipidemia; age; polypharmacy; lack of treatment of comorbidities; and lack of specific case definitions for comorbidities. ${ }^{7}$ However, with regard to smoking status, the percentage of current smokers enrolled in the tiotropium RCTs is similar to the percentage identified as current smokers in the observational studies included in our analysis.

Lastly, patients with recent unstable cardiac diseases (MI within 6 months and new unstable arrhythmia or severe heart failure within 1 year) were excluded from the tiotropium RCTs. Therefore, the findings in the tiotropium studies cannot be extended to these patients.

\section{Conclusion}

The clinical profile (defined by SOC) of patients with COPD treated in the tiotropium trial program appears to be largely in the range of clinical characteristics, including CV comorbidities reported for "real-life patients." Overall, patients in the tiotropium studies were comparable to those patients enrolled in the observational studies with regard to the severity of disease (GOLD stages III and IV).

\section{Acknowledgments}

The authors are fully responsible for all content and editorial decisions made, were involved at all stages of manuscript development, and have approved the final version for publication. Editorial assistance, supported financially by Boehringer Ingelheim and Pfizer, was provided by Godfrey Lisk of PAREXEL International during the preparation of this manuscript.

\section{Disclosure}

Marc Miravitlles has received speaker fees from Almirall, Boehringer Ingelheim, Pfizer, AstraZeneca, Chiesi, Esteve, GlaxoSmithKline, Menarini, Novartis, Talecris-Grifols, Takeda-Nycomed, and Novartis, and consulting fees from Almirall, Boehringer Ingelheim, Pfizer, GlaxoSmithKline, Gebro Pharma, MediImmune, Novartis, Talecris-Grifols, and Takeda-Nycomed.

David Price is a board member of Almirall, AstraZeneca, Boehringer Ingelheim, Chiesi, GlaxoSmithKline, Merck, Mundipharma, Medapharma, Novartis, Napp, Nycomed, Pfizer, Sandoz, and Teva. He or his research team has received grants and support for research in respiratory disease from the following organizations in the last 5 years: UK National Health Service, Aerocrine, AstraZeneca, Boehringer Ingelheim, Chiesi, GlaxoSmithKline, Merck, Mundipharma, Novartis, Nycomed, Orion, Pfizer, and Teva. 
In addition, he has consulted for Almirall, AstraZeneca, Boehringer Ingelheim, Chiesi, GlaxoSmithKline, Merck, Mundipharma, Medapharma, Novartis, Napp, Nycomed, Pfizer, Sandoz, and Teva; has received or has grants pending from the UK National Health Service, Aerocrine, AstraZeneca, Boehringer Ingelheim, Chiesi, GlaxoSmithKline, Merck, Mundipharma, Novartis, Nycomed, Orion, Pfizer, Takeda, and Teva; has received payments for lectures/ speaking from Almirall, AstraZeneca, Activaero, Boehringer Ingelheim, Chiesi, Cipla, GlaxoSmithKline, Kyorin, Novartis, Merck, Mundipharma, Pfizer, Takeda, and Teva; received payment for manuscript preparation from Merck, Mundipharma, and Teva; has had patents planned, pending or issued from AKL Ltd; received payment for the development of educational materials from GlaxoSmithKline; has shares in AKL Ltd, which produces phytopharmaceuticals and owns $80 \%$ of Research in Real Life Ltd and its subsidiary social enterprise, Optimum Patient Care; and has received payment for travel/accommodations/meeting expenses from Aerocrine, Boehringer Ingelheim, Napp, Novartis, Mundipharma, and Teva.

Klaus Rabe has provided legal consultation services or expert witness testimony to AstraZeneca, Boehringer Ingelheim, Chiesi Pharmaceutical, Novartis, MSD and GlaxoSmithKline. He has also received research funding from Altana Pharma, Novartis, AstraZeneca, MSD and Nycomed/Takeda. Ha has served on FDA and EMA panels for registration of drugs for COPD. Bartolome Celli has received grants from Boehringer Ingelheim, Almirall, GlaxoSmithKline, Novartis, Forrest, Aeris, and AstraZeneca. He has also received consultancy fees from GlaxoSmithKline, Boehringer Ingelheim, Dey, Altana, AstraZeneca, Almirall, Sepracor, Pfizer, Novartis, Rox, and Medimmune.

Norbert Metzdorf and Hendrik Schmidt are full-time employees of Boehringer Ingelheim Pharma GmbH \& Co KG.

\section{References}

1. Godwin M, Ruhland L, Casson I, et al. Pragmatic controlled clinical trials in primary care: the struggle between external and internal validity. BMC Med Res Methodol. 2003;3:28.

2. Travers J, Marsh S, Caldwell B, et al. External validity of randomized controlled trials in COPD. Respir Med. 2007;101(6):1313-1320.

3. Rothwell PM. External validity of randomised controlled trials: "to whom do the results of this trial apply?" Lancet. 2005;365(9453): 82-93.

4. Price D, Hillyer EV, van der Molen T. Efficacy versus effectiveness trials: informing guidelines for asthma management. Curr Opin Allergy Clin Immunol. 2013;13(1):50-57.

5. Travers J, Marsh S, Williams M, et al. External validity of randomised controlled trials in asthma: to whom do the results of the trials apply? Thorax. 2007;62(3):219-223.
6. Roche N, Reddel HK, Agusti A, et al; Respiratory Effectiveness Group. Integrating real-life studies in the global therapeutic research framework. Lancet Respir Med. 2013;1(10):e29-e30.

7. Chatila WM, Thomashow BM, Minai OA, Criner GJ, Make BJ. Comorbidities in chronic obstructive pulmonary disease. Proc Am Thorac Soc. 2008;5(4):549-555.

8. Barr RG, Celli BR, Mannino DM, et al. Comorbidities, patient knowledge, and disease management in a national sample of patients with COPD. Am J Med. 2009;122(4):348-355.

9. Carrasco-Garrido P, de Miguel-Díez J, Rejas-Gutierrez J, et al. Characteristics of chronic obstructive pulmonary disease in Spain from a gender perspective. BMC Pulm Med. 2009;9:2.

10. Finkelstein J, Cha E, Scharf SM. Chronic obstructive pulmonary disease as an independent risk factor for cardiovascular morbidity. Int J Chron Obstruct Pulmon Dis. 2009;4:337-349.

11. Sin DD, Anthonisen NR, Soriano JB, Agusti AG. Mortality in COPD: Role of comorbidities. Eur Respir J. 2006;28(6):1245-1257.

12. Divo M, Cote C, de Torres JP, et al; BODE Collaborative Group. Comorbidities and risk of mortality in patients with chronic obstructive pulmonary disease. Am J Respir Crit Care Med. 2012;186(2): 155-161.

13. Singh S, Loke YK, Enright PL, Furberg CD. Mortality associated with tiotropium mist inhaler in patients with chronic obstructive pulmonary disease: systematic review and meta-analysis of randomised controlled trials. BMJ. 2011;342:d3215.

14. Beasley R, Singh S, Loke YK, Enright P, Furberg CD. Call for worldwide withdrawal of tiotropium Respimat mist inhaler. BMJ. 2012;345: e7390.

15. Jones RC, Price D, Ryan D, et al; Respiratory Effectiveness Group. Opportunities to diagnose chronic obstructive pulmonary disease in routine care in the UK: a retrospective study of a clinical cohort. Lancet Respir Med. 2014;2(4):267-276.

16. Tashkin DP, Celli B, Senn S, et al; UPLIFT Study Investigators. A 4-year trial of tiotropium in chronic obstructive pulmonary disease. N Engl J Med. 2008;359(15):1543-1554.

17. Chan CK, Maltais F, Sigouin C, Haddon JM, Ford GT. A randomized controlled trial to assess the efficacy of tiotropium in Canadian patients with chronic obstructive pulmonary disease. Can Respir J. 2007;14(8): 465-472.

18. Niewoehner DE, Rice K, Cote C, et al. Prevention of exacerbations of chronic obstructive pulmonary disease with tiotropium, a once-daily inhaled anticholinergic bronchodilator: a randomized trial. Ann Intern Med. 2005;143(5):317-326.

19. Powrie DJ, Wilkinson TM, Donaldson GC, et al. Effect of tiotropium on sputum and serum inflammatory markers and exacerbations in COPD. Eur Respir J. 2007;30(3):472-478.

20. Moita J, Bárbara C, Cardoso J, et al. Tiotropium improves FEV1 in patients with COPD irrespective of smoking status. Pulm Pharmacol Ther. 2008;21(1):146-151.

21. Covelli H, Bhattacharya S, Cassino C, Conoscenti C, Kesten S. Absence of electrocardiographic findings and improved function with once-daily tiotropium in patients with chronic obstructive pulmonary disease. Pharmacotherapy. 2005;25(12):1708-1718.

22. Cooper CB, Celli BR, Jardim JR, et al. Treadmill endurance during 2-year treatment with tiotropium in patients with COPD: a randomized trial. Chest. 2013;144(2):490-497.

23. Bateman ED, Tashkin D, Siafakas N, et al. A one-year trial of tiotropium Respimat plus usual therapy in COPD patients. Respir Med. 2010; 104(10):1460-1472.

24. Agusti A, Calverley PM, Celli B, et al; Evaluation of COPD Longitudinally to Identify Predictive Surrogate Endpoints (ECLIPSE) investigators. Characterisation of COPD heterogeneity in the ECLIPSE cohort. Respir Res. 2010;11:122.

25. Curkendall SM, DeLuise C, Jones JK, et al. Cardiovascular disease in patients with chronic obstructive pulmonary disease, Saskatchewan Canada cardiovascular disease in COPD patients. Ann Epidemiol. 2006;16(1):63-70. 
26. de Lucas-Ramos P, Izquierdo-Alonso JL, Rodriguez-Gonzalez Moro JM, et al. CONSISTE study group. Chronic obstructive pulmonary disease as a cardiovascular risk factor. Results of a case-control study (CONSISTE study). Int J Chron Obstruct Pulmon Dis. 2012;7:679-686.

27. Fletcher MJ, Upton J, Taylor-Fishwick J, et al. COPD uncovered: an international survey on the impact of chronic obstructive pulmonary disease [COPD] on a working age population. BMC Public Health. 2011;11:612.

28. García-Olmos L, Alberquilla A, Ayala V, et al. Comorbidity in patients with chronic obstructive pulmonary disease in family practice: a cross sectional study. BMC Fam Pract. 2013;14:11.

29. Huiart L, Ernst P, Suissa S. Cardiovascular morbidity and mortality in COPD. Chest. 2005;128(4):2640-2646.

30. Jimenez-Garcia R, de Miguel-Díez J, Rejas-Gutierrez J, et al. Health, treatment and health care resources consumption profile among Spanish adults with diabetes and chronic obstructive pulmonary disease. Prim Care Diabetes. 2009;3(3):141-148.

31. Jones PW, Brusselle G, Dal Negro RW, et al. Health-related quality of life in patients by COPD severity within primary care in Europe. Respir Med. 2011;105(1):57-66.

32. Mannino DM, Thorn D, Swensen A, Holguin F. Prevalence and outcomes of diabetes, hypertension and cardiovascular disease in COPD. Eur Respir J. 2008;32(4):962-969.

33. Pasquale MK, Sun SX, Song F, Hartnett HJ, Stemkowski SA. Impact of exacerbations on health care cost and resource utilization in chronic obstructive pulmonary disease patients with chronic bronchitis from a predominantly Medicare population. Int J Chron Obstruct Pulmon Dis. 2012;7:757-764.

34. Rodríguez LA, Wallander MA, Martín-Merino E, Johansson S. Heart failure, myocardial infarction, lung cancer and death in COPD patients: a UK primary care study. Respir Med. 2010;104(11):1691-1699.

35. Schane RE, Walter LC, Dinno A, Covinsky KE, Woodruff PG. Prevalence and risk factors for depressive symptoms in persons with chronic obstructive pulmonary disease. J Gen Intern Med. 2008;23(11): 1757-1762.
36. Schnell K, Weiss CO, Lee T, et al. The prevalence of clinically-relevant comorbid conditions in patients with physician-diagnosed COPD: a cross-sectional study using data from NHANES 1999-2008. BMC Pulm Med. 2012;12:26.

37. Soriano JB, Visick GT, Muellerova H, Payvandi N, Hansell AL. Patterns of comorbidities in newly diagnosed COPD and asthma in primary care. Chest. 2005;128(4):2099-2107.

38. Sundh J, Stallberg B, Lisspers K, Montgomery SM, Janson C. Co-morbidity, body mass index and quality of life in COPD using the Clinical COPD Questionnaire. COPD. 2011;8(3):173-181.

39. Walker S, Fingleton J, Weatherall M, Beasley R. Limited generalisability of UPLIFT findings to clinical practice. Thorax. 2013;68(11): 1066-1067.

40. Patel AR, Hurst JR. Extrapulmonary comorbidities in chronic obstructive pulmonary disease: state of the art. Expert Rev Respir Med. 2011;5(5):647-662.

41. Verhamme KM, van Blijderveen N, Sturkenboom MC. Tiotropium and the risk of death in COPD. N Engl J Med. 2014;370(5):481-482.

42. Mathioudakis AG, Chatzimavridou-Grigoriadou V, Evangelopoulou E, Mathioudakis GA, Siafakas NM. Comparative mortality risk of tiotropium administered via handihaler or respimat in COPD patients: are they equivalent? Pulm Pharmacol Ther. 2014;28(2):91-97.

43. Tashkin D, Metzdorf N, Hallman C, Köenen-Bergmann M, Kupas K, Dahl R. Safety of Tiotropium in Renally Impaired Patients. Presented at the European Respiratory Society (ERS) Congress 2014. Abstract P-923. Munich: ERS; 2014. Available from: www.boehringer-ingelheim.com/ content/dam/internet/opu/com_EN/document/05_clinical_trials/qrcode/ ers_2014/tashkin.pdf. Accessed August 29, 2014. 


\section{Supplementary materials}

Table SI Clinical trials included in the pooled tiotropium HandiHaler ${ }^{\circledR}$ and Respimat $^{\circledR}$ analysis

\begin{tabular}{|c|c|c|c|c|}
\hline $\begin{array}{l}\text { Boehringer Ingelheim } \\
\text { trial number }\end{array}$ & $\begin{array}{l}\text { Trial duration } \\
\text { (weeks) }\end{array}$ & $\begin{array}{l}\text { Placebo-treated } \\
\text { patients }(\mathbf{N})\end{array}$ & $\begin{array}{l}\text { Tiotropium-treated } \\
\text { patients }(\mathbf{N})\end{array}$ & Reference \\
\hline \multicolumn{5}{|l|}{ HandiHaler ${ }^{\circledR}$ trials } \\
\hline $205.114 / 117$ & 48 & 191 & 279 & Casaburi et al' \\
\hline $205.115 / 128$ & 48 & 180 & 271 & Casaburi et al' \\
\hline $205.123\left(\right.$ ECLIPSE $\left.^{\circledR}\right)$ & 6 & 40 & 81 & Agusti et $\mathrm{al}^{2}$ \\
\hline 205.124 & 4 & 30 & 65 & McNicholas et al ${ }^{3}$ \\
\hline 205.130 & 24 & 201 & 209 & Brusasco et al ${ }^{4}$ \\
\hline 205.131 & 6 & 100 & 98 & O'Donnell et al ${ }^{5}$ \\
\hline 205.137 & 24 & 199 & 193 & Brusasco et $\mathrm{al}^{4}$ \\
\hline 205.2 I 4 (MISTRAL) & 48 & 510 & 500 & Dusser et $\mathrm{al}^{6}$ \\
\hline 205.215 & 12 & 54 & 46 & Verkindre et $\mathrm{al}^{7}$ \\
\hline 205.218 & 4 & 41 & 40 & Celli et $\mathrm{al}^{8}$ and Maltais et $\mathrm{a}^{9}$ \\
\hline 205.223 & 6 & 130 & $|3|$ & Maltais et $\mathrm{al}^{9}$ \\
\hline 205.230 & 25 & 53 & 55 & Casaburi et al ${ }^{10}$ \\
\hline 205.235 (UPLIFT $^{\circledR}$ ) & 210 & 3,006 & 2,986 & Tashkin et al" \\
\hline 205.247 & 25 & 117 & 117 & Kesten et al ${ }^{42}$ \\
\hline 205.256 (TIPHON) & 36 & 288 & 266 & Tonnel et al ${ }^{12}$ \\
\hline 205.257 & 12 & 403 & 1,236 & Beeh et $\mathrm{al}^{13}$ \\
\hline 205.259 (SAFE) & 48 & 305 & 608 & Chan et $\mathrm{al}^{14}$ \\
\hline 205.266 & 24 & 915 & 914 & Niewoehner et al ${ }^{15}$ \\
\hline 205.269 & 16 & 127 & 123 & Powrie et $\mathrm{al}^{16}$ \\
\hline 205.270 & 52 & 73 & 69 & Powrie et $\mathrm{al}^{16}$ \\
\hline 205.276 (SPRUCE) & 12 & 195 & 200 & Freeman et a $\left.\right|^{17}$ \\
\hline $205.28 I$ & 12 & 117 & 107 & Johansson et al $\left.\right|^{18}$ \\
\hline 205.282 (SAFE Portugal) & 12 & 164 & 147 & Moita et al ${ }^{19}$ \\
\hline 205.284 & 12 & 96 & 100 & Covelli et $\mathrm{a}^{20}$ \\
\hline 205.294 & 8 & 86 & 80 & Criner et $\mathrm{al}^{21}$ \\
\hline 205.301 & 12 & 244 & 228 & Magnussen et $\mathrm{a}^{22}$ \\
\hline 205.365 & 24 & 219 & 238 & Sciurba et $\mathrm{a}^{23}$ \\
\hline 205.368 (EXACTT) & 96 & 259 & 260 & Cooper et $\mathrm{al}^{24}$ \\
\hline \multicolumn{5}{|l|}{ Respimat $^{\circledR}$ trials } \\
\hline $205.25 \mathrm{I} / 252$ & 12 & 181 & 180 & Voshaar et $\mathrm{al}^{25}$ \\
\hline $205.254 / 255$ & 52 & 653 & 670 & Bateman et $\mathrm{al}^{26}$ \\
\hline 205.372 & 52 & 1,965 & 1,952 & Bateman et $\mathrm{al}^{27}$ \\
\hline $\mathrm{I}, 205.4$ & 4 & 55 & 53 & Littner et $\mathrm{a}^{28}$ \\
\hline I,205.14 & 24 & 429 & 427 & Abrahams et a $1^{29}$ \\
\hline
\end{tabular}

Note: Trial numbers refer to the Boehringer Ingelheim trials database.

Abbreviations: ECLIPSE, Evaluation of COPD Longitudinally to Identify Predictive Surrogate Endpoints; EXACTT, Exercise Endurance and COPD Treated With Tiotropium; MISTRAL, Mesure de l'Influence de SPIRIVA ${ }^{\oplus}$ sur les Troubles Respiratoires Aigus à Long terme [measuring the influence SPIRIVA ${ }^{\oplus}$ on acute respiratory disorders for the long term]; SAFE, SPIRIVA ${ }^{\oplus}$ Assessment of FEV ; SPRUCE, SPIRIVA $^{\oplus}$ Usual CarE; TIPHON, Tiotropium: Influence sur la Perception de l'amelioration des activités Habituelles Objectivée par une echelle Numerique; UPLIFT ${ }^{\oplus}$, Understanding the Potential Long-term Impacts on Function with Tiotropium; COPD, chronic obstructive pulmonary disease. 


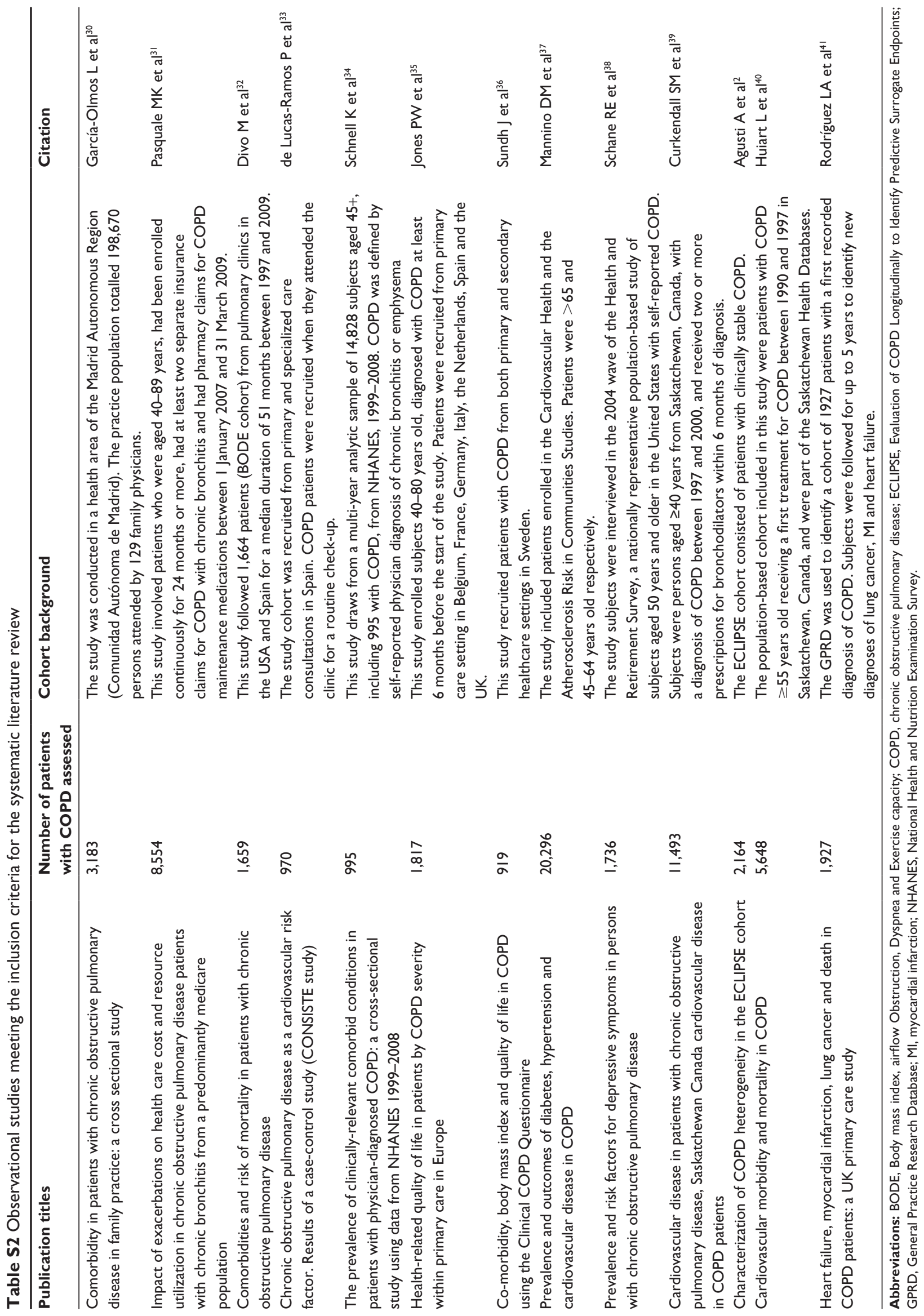



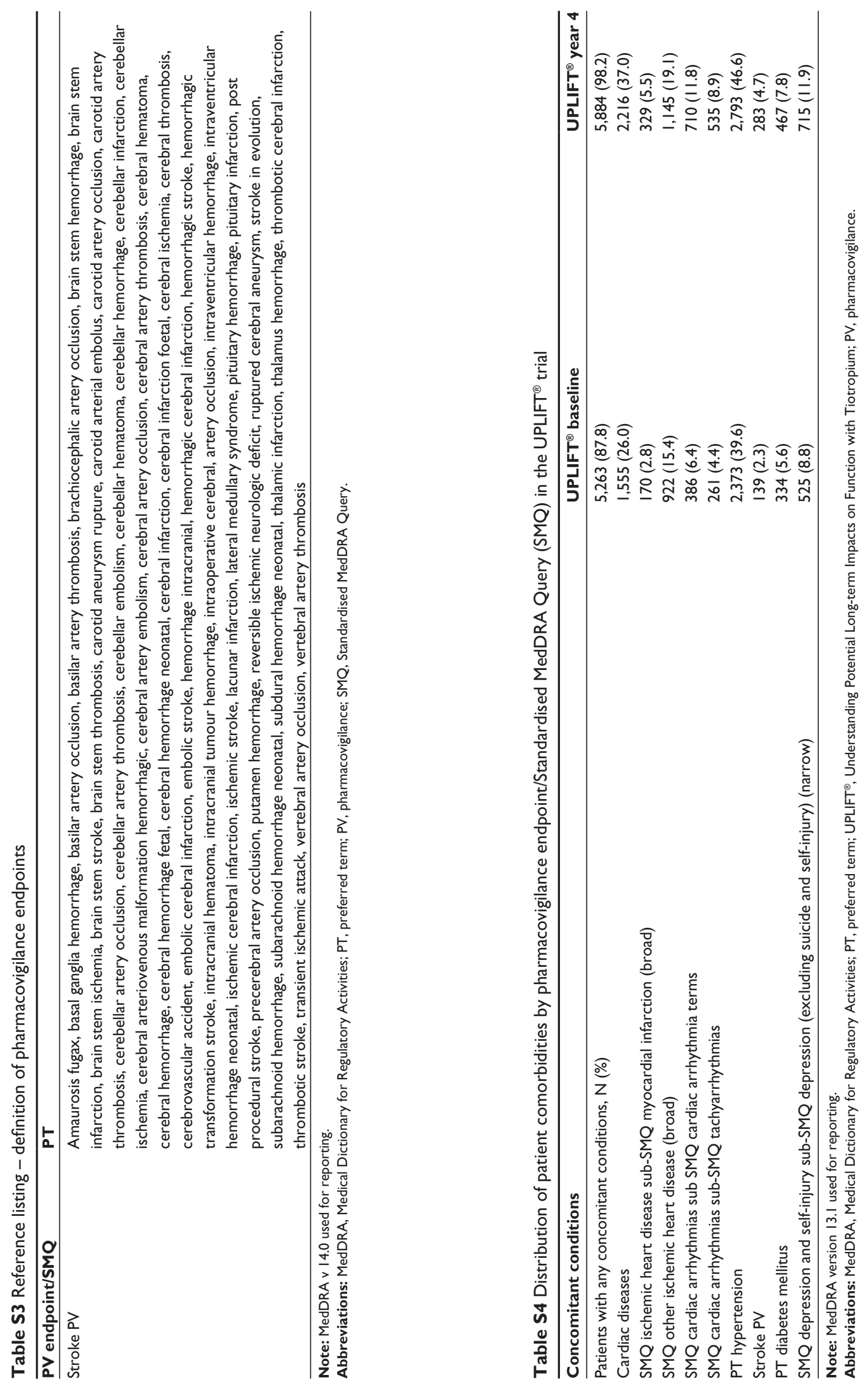


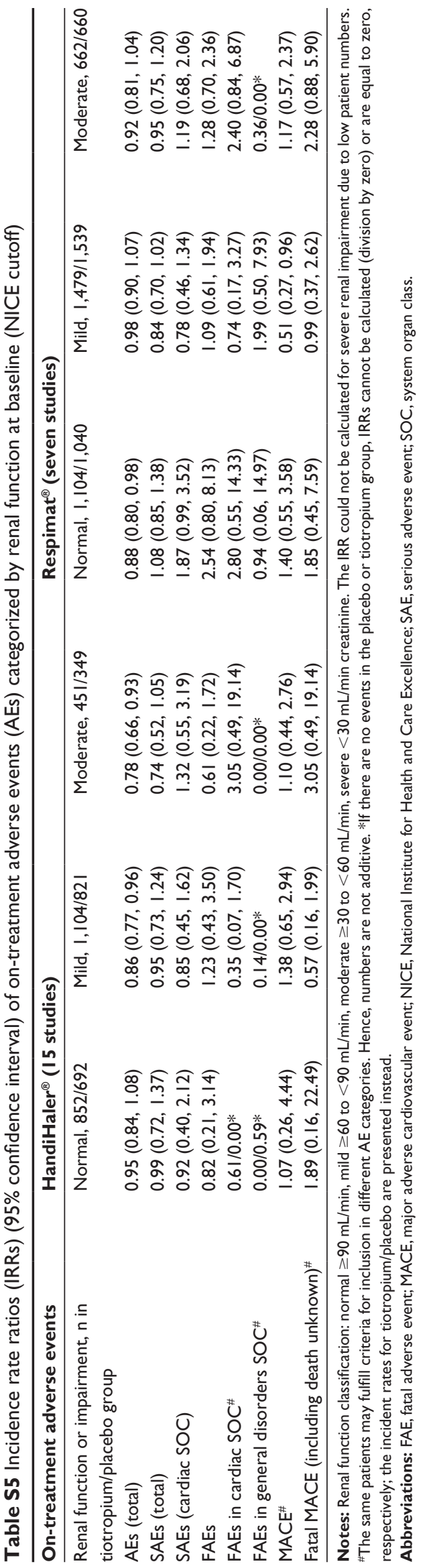

\section{References}

1. Casaburi R, Mahler DA, Jones PW, et al. A long-term evaluation of once-daily inhaled tiotropium in chronic obstructive pulmonary disease. Eur Respir J. 2002;19(2):217-224.

2. Agusti A, Calverley PM, Celli B, et al. Characterisation of COPD heterogeneity in the ECLIPSE cohort. Respir Res. 2010;11:122.

3. McNicholas WT, Calverley PM, Lee A, Edwards JC. Long-acting inhaled anticholinergic therapy improves sleeping oxygen saturation in COPD. Eur Respir J. 2004;23(6):825-831.

4. Brusasco V, Hodder R, Miravitlles M, Korducki L, Towse L, Kesten S. Health outcomes following treatment for six months with once daily tiotropium compared with twice daily salmeterol in patients with COPD. Thorax. 2003;58(5):399-404.

5. O'Donnell DE, Fluge T, Gerken F, et al. Effects of tiotropium on lung hyperinflation, dyspnoea and exercise tolerance in COPD. Eur Respir J. 2004;23(6):832-840.

6. Dusser D, Bravo ML, Iacono P. The effect of tiotropium on exacerbations and airflow in patients with COPD. Eur Respir J. 2006; 27(3):547-555.

7. Verkindre C, Bart F, Aguilaniu B, et al. The effect of tiotropium on hyperinflation and exercise capacity in chronic obstructive pulmonary disease. Respiration. 2006;73(4):420-427.

8. Celli B, ZuWallack R, Wang S, Kesten S. Improvement in resting inspiratory capacity and hyperinflation with tiotropium in COPD patients with increased static lung volumes. Chest. 2003;124(5):1743-1748.

9. Maltais F, Hamilton A, Marciniuk D, et al. Improvements in symptomlimited exercise performance over $8 \mathrm{~h}$ with once-daily tiotropium in patients with COPD. Chest. 2005;128(3):1168-1178.

10. Casaburi R, Kukafka D, Cooper CB, Witek TJ Jr, Kesten S. Improvement in exercise tolerance with the combination of tiotropium and pulmonary rehabilitation in patients with COPD. Chest. 2005; 127(3):809-817.

11. Tashkin DP, Celli B, Senn S, et al. A 4-year trial of tiotropium in chronic obstructive pulmonary disease. $N$ Engl J Med. 2008;359(15): $1543-1554$.

12. Tonnel AB, Perez T, Grosbois JM, Verkindre C, Bravo ML, Brun M. Effect of tiotropium on health-related quality of life as a primary efficacy endpoint in COPD. Int J Chron Obstruct Pulmon Dis. 2008:3(2):301-310.

13. Beeh KM, Beier J, Buhl R, Stark-Lorenzen P, Gerken F, Metzdorf N. [Efficacy of tiotropium bromide (Spiriva) in patients with chronicobstructive pulmonary disease (COPD) of different severities]. Pneumologie. 2006;60(6):341-346.

14. Chan CK, Maltais F, Sigouin C, Haddon JM, Ford GT. A randomized controlled trial to assess the efficacy of tiotropium in Canadian patients with chronic obstructive pulmonary disease. Can Respir J. 2007;14(8):465-472.

15. Niewoehner DE, Rice K, Cote C, et al. Prevention of exacerbations of chronic obstructive pulmonary disease with tiotropium, a once-daily inhaled anticholinergic bronchodilator: a randomized trial. Ann Intern Med. 2005;143(5):317-326.

16. Powrie DJ, Wilkinson TM, Donaldson GC, et al. Effect of tiotropium on sputum and serum inflammatory markers and exacerbations in COPD. Eur Respir J. 2007;30(3):472-478.

17. Freeman D, Lee A, Price D. Efficacy and safety of tiotropium in COPD patients in primary care - the SPiRiva Usual CarE (SPRUCE) study. Respir Res. 2007;8:45.

18. Johansson G, Lindberg A, Romberg K, Nordstrom L, Gerken F, Roquet A. Bronchodilator efficacy of tiotropium in patients with mild to moderate COPD. Prim Care Respir J. 2008;17(3):169-175.

19. Moita J, Barbara C, Cardoso J, et al. Tiotropium improves FEV1 in patients with COPD irrespective of smoking status. Pulm Pharmacol Ther. 2008;21(1):146-151.

20. Covelli H, Bhattacharya S, Cassino C, Conoscenti C, Kesten S. Absence of electrocardiographic findings and improved function with once-daily tiotropium in patients with chronic obstructive pulmonary disease Pharmacotherapy. 2005;25(12):1708-1718. 
21. Criner GJ, Sharafkhaneh A, Player R, et al. Efficacy of tiotropium inhalation powder in african-american patients with chronic obstructive pulmonary disease. COPD. 2008;5(1):35-41.

22. Magnussen H, Bugnas B, van NJ, Schmidt P, Gerken F, Kesten S. Improvements with tiotropium in COPD patients with concomitant asthma. Respir Med. 2008;102(1):50-56.

23. Sciurba FC, Siafakas N, Troosters T. The Efficacy and Safety of Tiotropium HandiHaler ${ }^{\circledR}, 18$ ìg, Once Daily Plus prn Salbutamol Versus Placebo Plus prn Salbutamolin COPD Subjects Naïve to Maintenance Therapy [abstract]. Presented at: Amercan Thoracic Society International Conferenc. Amercan Thoracic Society International Conference. 2011.

24. Cooper CB, Anzueto A, Decramer M, et al. Tiotropium reduces risk of exacerbations irrespective of previous use of inhaled anticholinergics in placebo-controlled clinical trials. Int J Chron Obstruct Pulmon Dis. 2011;6:269-275.

25. Voshaar T, Lapidus R, Maleki-Yazdi R, et al. A randomized study of tiotropium Respimat Soft Mist inhaler vs ipratropium pMDI in COPD. Respir Med. 2008;102(1):32-41.

26. Bateman E, Singh D, Smith D, et al. Efficacy and safety of tiotropium Respimat SMI in COPD in two 1-year randomized studies. Int J Chron Obstruct Pulmon Dis. 2010;5:197-208.

27. Bateman ED, Tashkin D, Siafakas N, et al. A one-year trial of tiotropium Respimat plus usual therapy in COPD patients. Respir Med. 2010;104(10):1460-1472.

28. Littner JA, Moroni-Zentgraf P, Sigmund R, Joseph E, Karpel J. Phase IIb dose-finding study of BEA2180 via Respimat ${ }^{\circledR}$ in patients with chronic obstructive pulmonary disease (COPD) [abstract]. Presented at: Asian Pacific Society of Respirology. Asian Pacific Society of Respirology. 2012.

29. Abrahams R, Moroni-Zentgraf P, Ramsdell J, Schmidt H, Joseph E, Karpel J. Safety and efficacy of the once-daily anticholinergic BEA2180 compared with tiotropium in patients with COPD. Respir Med. 2013;107(6):854-862.

30. Garcia-Olmos L, Alberquilla A, Ayala V, et al. Comorbidity in patients with chronic obstructive pulmonary disease in family practice: a cross sectional study. BMC Fam Pract. 2013;14:11.

31. Pasquale MK, Sun SX, Song F, Hartnett HJ, Stemkowski SA. Impact of exacerbations on health care cost and resource utilization in chronic obstructive pulmonary disease patients with chronic bronchitis from a predominantly Medicare population. Int J Chron Obstruct Pulmon Dis. 2012;7:757-764.
32. Divo M, Cote C, de Torres JP, et al. Comorbidities and risk of mortality in patients with chronic obstructive pulmonary disease. Am J Respir Crit Care Med. 2012;186(2):155-161.

33. de Lucas-Ramos P, Izquierdo-Alonso JL, Rodriguez-Gonzalez Moro JM, Frances JF, Lozano PV, Bellon-Cano JM. Chronic obstructive pulmonary disease as a cardiovascular risk factor. Results of a case-control study (CONSISTE study). Int J Chron Obstruct Pulmon Dis. 2012;7:679-686.

34. Schnell K, Weiss CO, Lee T, et al. The prevalence of clinically-relevant comorbid conditions in patients with physician-diagnosed COPD: a cross-sectional study using data from NHANES 1999-2008. BMC Pulm Med. 2012;12:26.

35. Jones PW, Brusselle G, Dal Negro RW, et al. Health-related quality of life in patients by COPD severity within primary care in Europe. Respir Med. 2011;105(1):57-66.

36. Sundh J, Stallberg B, Lisspers K, Montgomery SM, Janson C. Comorbidity, body mass index and quality of life in COPD using the Clinical COPD Questionnaire. COPD. 2011;8(3):173-181.

37. Mannino DM, Thorn D, Swensen A, Holguin F. Prevalence and outcomes of diabetes, hypertension and cardiovascular disease in COPD. Eur Respir J. 2008;32(4):962-969.

38. Schane RE, Walter LC, Dinno A, Covinsky KE, Woodruff PG. Prevalence and risk factors for depressive symptoms in persons with chronic obstructive pulmonary disease. J Gen Intern Med. 2008;23(11):1757-1762.

39. Curkendall SM, DeLuise C, Jones JK, et al. Cardiovascular disease in patients with chronic obstructive pulmonary disease, Saskatchewan Canada cardiovascular disease in COPD patients. Ann Epidemiol. 2006;16(1):63-70.

40. Huiart L, Ernst P, Suissa S. Cardiovascular morbidity and mortality in COPD. Chest. 2005;128(4):2640-2646.

41. Rodriguez LA, Wallander MA, Martin-Merino E, Johansson S. Heart failure, myocardial infarction, lung cancer and death in COPD patients: a UK primary care study. Respir Med. 2010;104(11):1691-1699.

42. Kesten S, Celli B, Decramer M, Leimer I, Tashkin D. Tiotropium HandiHaler $^{\circledR}$ in the treatment of COPD: A safety review. Int J Chron Obstruct Pulmon Dis. 2009;4:397-409.
International Journal of COPD

\section{Publish your work in this journal}

The International Journal of COPD is an international, peer-reviewed journal of therapeutics and pharmacology focusing on concise rapid reporting of clinical studies and reviews in COPD. Special focus is given to the pathophysiological processes underlying the disease, intervention programs, patient focused education, and self management protocols.

\section{Dovepress}

This journal is indexed on PubMed Central, MedLine and CAS. The manuscript management system is completely online and includes a very quick and fair peer-review system, which is all easy to use. Visit http://www.dovepress.com/testimonials.php to read real quotes from published authors. 